\title{
PENINGKATAN KOMPETENSI GURU UNTUK MENGEMBANGKAN PROFESI MELALUI PEMBIMBINGAN PENULISAN PTK BAGI GURU SMK
}

\author{
GIYARSIH \\ Pengawas SMK Kulon Progo \\ Email: asih125@yahoo.co.id
}

\begin{abstract}
ABSTRAK
Tujuan penelitian ini untuk melatih guru agar mampu melakukan pengembangan profesi melalui pendampingan dan pembimbingan, membina guru dalam mempertinggi kompetensi profesionalnya, membina guru dalam mengembangkan karir profesi dan kepangkatannya, dan membantu guru dalam memperbaiki mutu proses pembelajaran di kelas melalui pendampingan dan pembimbingan agar guru semakin profesional, sehingga proses belajar mengajar menjadi lancar dan prestasi belajar siswa meningkat. Setelah mengetahui permasalahan ini, pengawas dapat mengoptimalisasi kompetensi guru melalui pendampingan dan pembimbingan bagi Guru SMK Kabupaten Kulon Progo. Metode penelitian menggunakan Penelitian Tindakan Sekolah (PTS). Subyek penelitian adalah guru binaan yang membutuhkan pendampingan intensif, pada sekolah binaan di kabupaten Kulon Progo. Dari hasil penelitian yang diperoleh dari sembilan guru binaan dapat disimpulkan pendampingan dan pembimbingan dapat meningkatkan pengetahuan guru tentang pengembangan profesi; meningkatkan motivasi guru untuk melakukan kegiatan pengembangan profesi; meningkatkan motivasi guru untuk menulis PTK; meningkatkan aktivitas menulis bagi guru dan dapat meningkatkan profesionalisme guru.
\end{abstract}

Kata Kunci: Kompetensi Guru, Pengembangan Profesi, Pendampingan dan Pembimbingan.

\section{PENDAHULUAN}

Masih ada guru di lingkungan Kabupaten Kulon Progo yang enggan melakukan kegiatan pengembangan profesi dalam hal melakukan Penelitian tindakan Kelas (PTK), hal ini disebabkan karena beberapa hal antara lain: pengetahuan guru terkait dengan pengembangan profesi, tingginya kesibukan guru, kurangnya bimbingan dan pendampingan. Minat guru untuk melakukan kegiatan pengembangan profesi masih rendah, bimbingan dalam pengembangan profesi belum maksimal, pendampingan dalam melaksanakan kegiatan pengembangan profesi masih kurang, banyaknya dan beratnya beban guru. Jumlah guru golongan IV/a yang usul penilaian Angka Kredit (PAK) sebanyak 203, yang lolos ke IV/b hanya satu (Balai Dikmen KP, 2020).

Pengembangan professionalisme guru perlu dilakukan, sebagai upaya untuk meningkatkan kompetensi guru maupun siswa disamping itu juga untuk mengimbangi pengakuan profesi guru oleh pemerintah. Usaha guru untuk meningkatkan profesionalisme, menunjukkan komitmen dan tanggungjawab yang tinggi merupakan imbal balik atas penghargaan profesi yang sudah diberikan oleh pemerintah. Agar prestasi belajar siswa maksimal, guru harus meningkatkan kualitas pembelajaran secara kontinu. Seperti yang disampaikan oleh Mustofa bahwa pemerintah telah berusaha meningkatkan profesionalisme guru melalui MGMP, sikap profesional dan inovatif guru perlu diupayakan pemerintah agar dapat melaksanakan peran dan tugasnya mendidik masyarakat menuju kehidupan yang lebih baik dan berkualitas (Mustofa, 2007:87). Upaya mengembangkan profesi dengan meningkatkan kompetensi guru ditempuh dengan jalan guru mengikuti pendidikan dan pelatihan, untuk memperbaiki pembelajaran di kelas, guru perlu melaksanakan PTK. Hal ini sesuai dengan pendapat Dinisiswani dan Suwarno, yang menyatakan bahwa dengan pelatihan dan pendampingan dapat meningkatkan wawasan dan keterampilan tentang penyusunan proposal, pelaksanaan PTK, dan penyusunan laporan PTK (Suwarno, 2016:10). Dengan pelatihan dan pendampingan dapat meningkatkan pemahaman guru tentang penulisan PTK, hal ini sesuai dengan pendapat Padrul Jana dan Bayu Pamungkas yang mengatakan bahwa dengan pelatihan 
dapat meningkatkan pemahaman guru dalam menyusun proposal PTK, melaksanakan penelitian dan membuat laporan hasil PTK (Padruljana dan Bayu Pamungkas, 2018: 45).

Beberapa guru di lingkungan Kabupaten Kulon Progo masih ada yang belum melakukan kegiatan pengembangan profesi, karena pengetahuan guru tentang pengembangan profesi masih kurang dan motivasi guru untuk menulis PTK masih rendah. Guru perlu dimotivasi agar melaksanakan penelitian dan menulisnya dalam bentuk laporan PTK. Keberhasilan dalam mendorong atau memotivasi guru melakukan PTK sudah dilaksanakan dalam penelitiannya Madzuki dan Muhammad Noor Kholid yang menyebutkan bahwa ada 23 guru matematika SMA/SMK dan 5 orang guru matematika SMP Muhammadiyah di Klaten yang mampu melaksanakan kegiatan PTK secara berkelompok dan 20 guru melaksanakan PTK dan penulisan artikel ilmiah (Madzuki dan Muhammad Noor Kholid, 2017: 126).

Dari data kenaikan pangkat guru di Balai Pendidikan Menengah kabupaten Kulon Progo menunjukkan bahwa tahun 2020 hanya seorang guru golongan IV/a yang lolos ke IV/b. Mereka terkendala pada pengembangan profesi, khususnya penelitian. Dengan meningkatnya golongan ruang guru dari jabatan yang lebih rendah ke golongan yang lebih tinggi, berarti terjadi peningkatan profesionalisme guru. Untuk itulah diperlukan adanya penelitian tentang meningkatkan kompetensi guru untuk mengembangkan profesi melalui pendampingan dan pembimbingan penulisan PTK pada kegiatan Bimlat di Sekolah Binaan Kabupaten Kulon Progo.

Cara terbaik untuk mengembangkan profesi guru dalam melakukan dan membuat laporan PTK adalah metode pendampingan dan pembimbingan penulisan PTK melalui kegiatan Bimlat dan supervisi akademis. Seperti yang disampaikan dalam penelitian I Gede Astawan yang menyimpulkan bahwa dengan Bimlat dan pendampingan terjadi peningkatan kemampuan guruguru SD di Gugus VII Kecamatan Sukasada dalam menulis karya ilmiah penyusunan PTK (I Gede Astawan, 2019: 117).

Menurut Suharsimi Arikunto dalam Dinisiswani dan Suharno, PTK terdiri dari kata penelitian, tindakan, dan kelas. Penelitian adalah kegiatan mencermati objek menggunakan aturan tertentu untuk memperoleh data dan informasi yang bermanfaat dalam meningkatkan mutu. Tindakan adalah kegiatan yang sengaja dilakukan dengan tujuan tertentu, sedangkan kelas adalah sekelompok siswa dalam waktu yang sama menerima pelajaran yang sama dari seorang guru (Dinisiswani dan Suharno, 2016: 3).

Menurut Agus Purnomo, Bimlat adalah kegiatan diskusi dan praktik dalam forum untuk menyelesaikan masalah (Agus Purnomo, 2015:28). Bertolak dari itu, diharapkan motivasi dan aktivitas peserta Bimlat dalam meningkatkan profesinya sebagai peneliti semakin meningkat. Dengan demikian, peserta Bimlat akan merasakan manfaat mengikuti Bimlat dan pendampingan PTK. Disamping itu dengan adanya program pendampingan melalui supervisi akademis guru diharapkan dapat meningkatkan motivasi dan aktivitas siswa dalam proses pembelajaran sehingga mereka dapat belajar secara enjoy, aktif, kreatif, mandiri, dan mempermudah pemahaman konsep yang ada. Dengan demikian, siswa akan merasakan manfaat mempelajari ilmu pengetahuan yang konsepnya sering dibutuhkan untuk memecahkan permasalahan yang muncul dalam kehidupan nyata. Dan pembelajaran yang disampaikan oleh guru tidak hanya monoton saja, atau hanya menggunakan metode konvensional. Hal ini diupayakan untuk variasi dalam pembelajaran dan mengurangi kebosanan anak.

Identifikasi masalah dari penelitian ini adalah kurangnya pengetahuan guru tentang pengembangan profesi yang akan berdampak pada tingkat profesionalisme guru rendah, tingginya kesibukan guru sehingga waktu guru untuk menulis PTK sedikit, kurangnya bimbingan dalam kegiatan pengembangan profesi yang akan berdampak pada rendahnya motivasi guru untuk melakukan PTK, kurangnya pendampingan dalam melaksanakan kegiatan PTK. Rumusan masalah yaitu Bagaimanakah pembimbingan dan pelatihan (Bimlat) dapat meningkatkan pengetahuan guru tentang pengembangan profesi yang berdampak pada peningkatan profesionalisme guru? Apakah dengan adanya waktu yang cukup akan berdampak pada banyaknya guru yang menulis PTK? Bagaimanakah pembimbingan dalam kegiatan 
pengembangan profesi berdampak pada peningkatan motivasi guru untuk melakukan PTK Bagaimanakan pendampingan dalam melaksanakan kegiatan PTK berdampak pada peningkatan jumlah guru yang melakukan PTK.

\section{METODE PENELITIAN}

Jenis penelitian dalam penelitian ini adalah penelitian tindakan sekolah (PTS), subyek penelitian adalah sembilan guru SMK Negeri 1 Nanggulan kabupaten Kulon Progo yang tergabung dalam kelompok A Bimlat Sekolah binaan SMK kabupaten Kulon Progo, waktu penelitian pada semester 2 tahun pelajaran 2020/2021. Tempat penelitian adalah SMK N Nanggulan. Cara pelaksanaannya yaitu: diawali dengan melaksanakan Bimlat, kemudian melakukan pembimbingan guru tentang pembuatan judul PTK, dilanjutkan dengan pemberian kesempatan kepada guru untuk mempresentasikan judul PTK. pembimbingan kedua tentang Proposal PTK, pendampingan guru tentang pembuatan Proposal PTK, dilanjutkan dengan pemberian kesempatan kepada guru untuk mempresentasikan Proposal PTK. pembimbingan ketiga tentang laporan Hasil PTK, Langkah selanjutnya mendampingi guru dalam melaksanakan PTK. Dalam mendampingi guru dalam melaksanakan PTK, dilakukan diskusi konsultasi sehingga guru dapat menemukan sendiri permasalahannya sampai proses pembelajaran berikutnya semakin baik. Kemudian melakukan pembimbingan guru tentang pembuatan laporan Hasil PTK, masing-masing guru dipersilahkan untuk mengisi angket terkait dengan model pendampingan dan pembimbingan. Pada kegiatan terakhir sembilan guru diberi kesempatan untuk mempresentasikan laporan Hasil PTK.

Pelaksanaan Penelitian Tindakan Sekolah mencakup empat tahap: 1) Perencanaan. 2) Pelaksanaan Tindakan: Menyajikan materi tentang Penulisan PTK (dua siklus), masing-masing siklus tiga kali pertemuan. 3) Pengamatan Proses Tindakan: Penulis melaksanakan PTS sendiri tanpa kolaborator pengumpulan data dan pengamatan pembelajaran di sekolah. 4) Refleksi, peneliti merefleksi bersama semua peserta yang mengikuti tindakan yang bertempat di ruang sidang. Para peserta dibagikan angket tentang Bimlat dan pendampingan penulisan PTK. Hasil refleksi dipakai untuk memperbaiki dan menyempurnakan proses tindakan, untuk tahap perencanaan siklus selanjutnya. Teknik pengumpulan data dalam PTS ini disajikan pada tabel 1 berikut:

Tabel 1. Teknik Pengumpulan Data

\begin{tabular}{|c|c|c|c|}
\hline & Sumber Data & Jenis Data & Tehnik pengumpulan \\
\hline 1 & $\begin{array}{l}\text { Peserta } \\
\text { Bimlat }\end{array}$ & $\begin{array}{l}\text { - Kompetensi Guru: Motivasi untuk melakukan } \\
\text { pengembangan profesi dan aktivitas guru } \\
\text { untuk menulis PTK } \\
\text { - Pengembangan Profesi: pengetahuan guru } \\
\text { tentang pengembangan profesi } \\
\text { - Hasil kerja peserta Bimlat Siklus I } \\
\text { - Hasil kerja peserta Bimlat Siklus II }\end{array}$ & $\begin{array}{ll}\text { - } & \text { Angket } \\
\text { - } & \text { Observasi }\end{array}$ \\
\hline
\end{tabular}

Data yang berbentuk angka disajikan menggunakan tabel, ditentukan nilai rata-ratanya dan dipersentasikan. Sedangkan untuk data yang tidak berbentuk angka, dianalisis dengan menggunakan metode analisis kualitatif. Yaitu dengan mengadakan wawancara atau memadukan hasil pengamatan antara peneliti dengan peserta Bimlat.

\section{HASIL DAN PEMBAHASAN}

PTS dilaksanakan dalam kegiatan Bimlat di sekolah binaan, penelitian ini berusaha meningkatkan motivasi dan aktivitas melakukan penelitian bagi guru SMK maupun memperbaiki proses pembelajaran di sekolah binaan. PTS dilaksankan dengan dua siklus, tiap siklus hasilnya dianalisis keberhasilan maupun kegagalan tindakan sebagai bahan pertimbangan dan refleksi untuk perbaikan pembelajaran selanjutnya. Penelitian diawali 
dengan sekolah mengadakan MOu dengan LPMP, yang diawali dengan melakukan Bimlat dan dilanjutkan dengan pedampingan dan pembimbingan.

Setelah siklus kedua selesai dijalankan, peserta diberi angket model Bimlat penulisan PTK. Kemudian para peserta Bimlat dimohon untuk mengumpulkan judul PTK dengan benar, proposal penelitian dengan benar, dan membuat sistematika laporan hasil penelitian dalam bentuk soft-copy maupun hard-copy.

\section{- Siklus Pertama}

Rencana: bersama widyaiswara mendampingi dan membimbing peserta dalam mempresentasikan Judul, proposal dan instrument PTK. Pelaksanaan: Setiap tindakan (tindakan satu, dua dan tiga) melaksanakan pendampingan dan pembimbingan PTK dalam kegiatan Bimlat. Kegiatan diawali dari penjelasan secara umum dari nara sumber, kegiatan dihadiri oleh 53 peserta dari jenjang SD, SMP, SMA dan SMK yang berasal dari kabupaten Bantul, Sleman, kota Yogyakarta dan yang terbanyak dari Kulon Progo. Jumlah peserta terbanyak dari jenjang SMK yaitu dari SMK Negeri 1 Nanggulan. Dari 53 peserta dibagi ke dalam kelompok kecil, masing-masing peserta diberi tugas untuk membuat judul PTK. Dari semua peserta di atas dikelompokkan menjadi empat kelas, setiap kelas didampingi dan dibimbing oleh LPMP. Kelas A berjumlah 9 (Sembilan) peserta yang didampingi dan dibimbing oleh LPMP dan pengawas pembina. Pertemuan ke-1: mendampingi dan membimbing peserta dalam mempresentasikan Judul PTK, Pertemuan ke 2: mendampingi dan membimbing peserta dalam mempresentasikan proposal PTK, Pertemuan ke-3: mendampingi dan membimbing peserta dalam mempresentasikan instrumen penelitian. Pengamatan (Observasi): Pertemuan Pertama, hasil pengamatan bersama kolaborator pada siklus pertama, pertemuan pertama: 9 (sembilan) peserta mengikuti kegiatan pendampingan dan pembimbingan ada 8 (delapan) peserta yang sudah mempresentasikan, satu peserta belum mempresentasikan judul PTK; Pertemuan kedua, hasil pengamatan bersama kolaborator pada siklus pertama, pertemuan kedua: 9 peserta hadir, dari jumlah peserta yang hadir satu peserta yang belum mempresentasikan judul saat pertemuan pertama, pada pertemuan kedua sudah mempresentasikan judul PTK. Dari semua peserta yang mempresentasikan proposal PTK ada 1 (satu) peserta yang sudah selesai sampai bab III, namun belum ada indikator keberhasilannya. Ada 4 (empat) peserta yang sudah selesai bab I dengan benar, 2 (dua) peserta yang belum menyelesaikan bab II dan 3 (tiga) peserta yang belum menyelesaikan bab III. Peserta yang lain sudah menyelesaikan tiga bab dengan beberapa revisi. Pertemuan ketiga, hasil pengamatan bersama kolaborator pada siklus pertama, pertemuan ketiga: semua peserta sudah menyelesaikan bab I dengan benar, 5 (lima) peserta sudah menyelesaikan bab II dengan benar dan 1 (satu) peserta belum membuat bab III. Peserta yang lain sudah menyelesaikan tiga bab dengan beberapa revisi. Bagi peserta yang belum bisa menyelesaikan tugas sesuai target, disarankan untuk menyelesaikan, jika ada kendala bisa pembimbingan dengan daring.

\begin{tabular}{cccccc}
\multicolumn{3}{c}{ Tabel 2. Hasil Observasi dan Hasil Kerja Peserta Bimlat Siklus I } \\
\hline No & \multicolumn{1}{c}{ Kriteria } & \multicolumn{2}{c}{ Hasil Observasi } & \multicolumn{2}{c}{ Hasil Kerja } \\
\cline { 2 - 6 } & $\begin{array}{l}\text { Jumlah } \\
\text { Peserta }\end{array}$ & Persen-tase & $\begin{array}{l}\text { Jumlah } \\
\text { Peserta }\end{array}$ & Persen-tase \\
\hline 1 & $\begin{array}{l}\text { Sangat Tinggi } \\
(80-100 \%)\end{array}$ & 3 & 33,33 & 2 & 22,22 \\
2 & $\begin{array}{l}\text { Tinggi } \\
(70-79 \%)\end{array}$ & 0 & 66,67 & 6 & 66,67 \\
4 & $\begin{array}{l}\text { Cukup } \\
(60-69 \%)\end{array}$ & 0 & 0 & 1 & 11,11 \\
$\begin{array}{l}\text { Rendah } \\
(0-59 \%)\end{array}$ & \multicolumn{1}{c}{ Jumlah } & 9 & 100 & 0 & 0 \\
\cline { 2 - 6 }
\end{tabular}


Dari table di atas, dapat dideskripsikan bahwa hasil pengamatan pada siklus I, masih ada 1 (satu) peserta atau 11,11\% yang memperoleh nilai cukup. Refleksi: berdasarkan temuan dalam serangkaian kegiatan pada siklus I serta hasil refleksi antara peneliti dengan kolaborator pada saat pendampingan dan pembimbingan diperoleh hasil bahwa peserta Bimlat sudah aktif dalam kegiatan Bimlat, sudah menulis PTK dari judul, proposal dan instrumen penelitian. Walaupun masih ada 5 guru yang belum menyelesaikan sampai bab III dan 3 guru yang belum menyelesaikan instrumen penelitiannya. Pengembangan profesi dilanjutkan dengan melaksanakan penelitian sampai melakukan seminar hasil penelitian dan menulisnya dalam bentuk laporan PTK.

\section{- Siklus kedua}

Rencana: bersama widyaiswara mendampingi dan membimbing peserta dalam mengolah data hasil penelitian dan dalam melakukan Refleksi Siklus I, II dan penulisan laporan PTK serta bahan tayang seminar; Pelaksanaan: Setiap tindakan (tindakan satu dan dua) melaksanakan pembimbingan dan pendampingan PTK dalam kegiatan Bimlat melalui pembimbingan individual. Pertemuan ke- 1: mendampingi dan membimbing peserta dalam mengolah data hasil penelitian dan dalam melakukan Refleksi Siklus I; Pertemuan ke- 2: mendampingi dan membimbing peserta dalam mengolah data hasil penelitian dan dalam melakukan Refleksi Siklus II; Pertemuan ke- 3: mendampingi dan membimbing peserta dalam membuat Laporan PTK dan bahan tayang seminar. Pengamatan (Observasi): Pertemuan Pertama, hasil pengamatan bersama kolaborator pada siklus ke dua, pertemuan pertama: Hasil observasi Pertemuan pertama Siklus II terlampir pada lampiran 6: 9 (sembilan) peserta mengikuti kegiatan pendampingan dan pembimbingan ada 9 (sembilan) peserta yang sudah mempresentasikan hasil pengolahan data dan refleksi siklus I, Pertemuan kedua, hasil pengamatan bersama kolaborator pada siklus kedua, pertemuan kedua: 9 (sembilan) peserta mengikuti kegiatan pendampingan dan pembimbingan ada 8 (delapan) peserta yang sudah mempresentasikan hasil pengolahan data dan refleksi siklus I, satu peserta pembimbingan dilanjutkan secara on line via whatsapp; Pertemuan ketiga: ada 5 (lima) peserta yang sudah sampai bab V, ada 4 (empat) peserta yang sudah selesai sampai bab V dan bahan tayang seminar. Terlihat dari persentase perolehan nilai yang penulis kriteriakan seperti tertera pada tabel 3 berikut:

Tabel 3. Hasil Observasi dan Hasil Kerja Peserta Bimlat Siklus II

\begin{tabular}{clcccc}
\hline No & Kriteria & \multicolumn{2}{c}{ Hasil Observasi } & \multicolumn{2}{c}{ Hasil Kerja } \\
\cline { 3 - 6 } & $\begin{array}{c}\text { Jumlah } \\
\text { Peserta }\end{array}$ & $\begin{array}{c}\text { Persen- } \\
\text { tase }\end{array}$ & $\begin{array}{c}\text { Jumlah } \\
\text { Peserta }\end{array}$ & $\begin{array}{c}\text { Persen- } \\
\text { tase }\end{array}$ \\
\hline 1 & $\begin{array}{l}\text { Sangat Tinggi } \\
(80-100 \%)\end{array}$ & 4 & 44,44 & 7 & 77,78 \\
2 & $\begin{array}{l}\text { Tinggi } \\
(70-79 \%)\end{array}$ & 5 & 55,56 & 2 & 22,22 \\
3 & $\begin{array}{l}\text { cukup } \\
(60-69 \%)\end{array}$ & 0 & 0 & 0 & 0 \\
\hline $\begin{array}{l}\text { Rendah } \\
(0-59 \%)\end{array}$ & 9 & 100 & 0 & 0 \\
\hline Jumlah & 9 & & 9 & 100 \\
\hline
\end{tabular}

Hasil pengamatan pada siklus II, menunjukkan bahwa semua peserta memperoleh nilai minimal baik. 
Vol 1. No. 3, Juli 2021 P-ISSN : 2775-0019, e-ISSN : 2774-6283

Tabel 4. Hasil Ketuntasan Peserta Bimlat Setelah Siklus I dan II

\begin{tabular}{|c|c|c|c|c|c|}
\hline \multirow[b]{2}{*}{ No } & \multirow[b]{2}{*}{ Kriteria } & \multicolumn{2}{|c|}{ Siklus I } & \multicolumn{2}{|c|}{ Siklus II } \\
\hline & & $\begin{array}{l}\text { Jumlah } \\
\text { Peserta }\end{array}$ & Persentase & $\begin{array}{l}\text { Jumlah } \\
\text { Peserta }\end{array}$ & Persentase \\
\hline 1 & $\begin{array}{l}\text { Tuntas } \\
\text { Perorangan, jika } \\
\text { mencapai KKM } \\
(61)\end{array}$ & 7 & 77,78 & 9 & 100 \\
\hline 2 & $\begin{array}{l}\text { Belum tuntas } \\
\text { Perorangan, jika } \\
\text { belum mencapai } \\
\text { KKM (61) }\end{array}$ & 2 & 22,22 & 0 & 0 \\
\hline 3 & $\begin{array}{l}\text { Tuntas klasikal, } \\
\text { jika } 85 \% \text { jumlah } \\
\text { peserta Bimlat } \\
\text { memperoleh nilai } \\
\text { lebih dari atau } \\
\text { sama dengan } \\
\text { KKM }\end{array}$ & & & \multicolumn{2}{|c|}{$\begin{array}{c}\text { Sudah tuntas secara } \\
\text { klasikal }\end{array}$} \\
\hline 4 & $\begin{array}{l}\text { Belum Tuntas } \\
\text { secara klasikal, } \\
\text { jika jumlah } \\
\text { peserta Bimlat } \\
\text { yang mencapai } \\
\text { KKM }<85 \% \\
\end{array}$ & \multicolumn{2}{|c|}{$\begin{array}{l}\text { Secara klasikal belum } \\
\text { tuntas }\end{array}$} & & \\
\hline
\end{tabular}

Untuk memperoleh tanggapan peserta tentang Bimlat dan pembimbingan PTK peserta Bimlat diberi angket yang menggunakan empat pilihan yaitu SS (sangat Setuju), S (Setuju), KS (Kurang Setuju) dan TS (Tidak Setuju). Dari hasil angket yang telah diisi oleh peserta diklat yang menyatakan sangat setuju, bahwa Workshop dan pembimbingan penulisan PTK dapat meningkatkan kompetensi guru dalam hal menggali masalah penelitian sampai dapat menyelesaikan tugas PTK sebesar 44,44\%. Perolehan hasil angket tertinggi terkait dengan motivasi guru dan tingkat pemahaman guru terkait materi PTK sebesar 66,67\% menyatakan sangat setuju.

Hasil penelitian menunjukkan bahwa pengetahuan dan keterampilan guru tentang PTK semakin meningkat setelah peserta diberi Bimlat, pendampingan dan pembimbingan. Hal ini sesuai dengan hasil penelitian Wahyudi dkk, yang mengatakan bahwa workshop dan pendampingan dapat meningkatkan secara signifikan terhadap pemahaman dan keterampilan PTK dalam Pengembangan Keprofesian Berkelanjutan bagi Guru Sekolah Dasar (Wahyudi dkk, 2018: 98). Hasil penelitian juga menunjukkan bahwa guru merasa senang dan termotivasi saat didampingi dan dibimbing. Hal ini sesuai dengan hasil penelitian Masduki dan M. Noor Kholid, yang mengatakan bahwa pelatihan dan pendampingan mampu memotivasi para guru melaksanakan kegiatan PTK serta mempresentasikannya (Masduki dan M. Noor Kholid, 2017: 170). Dari hasil kegiatan Bimlat, pendampingan dan pembimbingan, menunjukkan bahwa guru sudah berhasil membuat dan mempresentasikan laporan hasil PTK. Hal ini sesuai dengan hasil penelitian Sigit Pambudi, yang mengatakan bahwa dengan pelatihan dan pendampingan pelaksanaan PTK maka profesionalisme, wawasan guru tentang PTK dan kejelasan guru dalam membuat laporan PTK meningkat (Sigit Pambudi, 2019: 61). Didukung pula oleh hasil penelitian Somatanaya dkk, yang mengatakan bahwa dengan pelatihan dapat membantu guru membuat laporan PTK yang berkualitas (Somatanaya dkk, 2017: 174). Disamping itu didukung oleh hasil penelitian Subakdi, yang mengatakan bahwa keterampilan guru SMP kelas VIII di 
SMP binaan kabupaten Sragen Semester I tahun pelajaran 2017/2018 dalam menyusun PTK dapat ditingkatkan melalui pembimbingan (Subakdi, 2018: 84). Disamping itu didukung pula oleh hasil penelitian Rahmatul Hayati dkk, yang mengatakan bahwa pelatihan dan pembimbingan PTK dapat meningkatkan kemampuan guru dalam melakukan dan membuat PTK (Rahmatul Hayati dkk, 2020: 175).

Disamping itu hasil penelitian menunjukkan bahwa setelah dilakukan tindakan dan perbaikan, diperoleh hasil kerja peserta Bimlat setelah siklus kedua lebih dari hasil kerja peserta Bimlat setelah siklus pertama. Bimlat, pendampingan dan pembimbingan dapat meningkatkan kompetensi guru dalam mengembangkan profesi melalui PTK.

\section{SIMPULAN}

Melalui Kegiatan Bimlat penulisan PTK dapat meningkatkan motivasi guru dalam melaksanakan PTK sehingga profesi guru meningkat. Bimlat dan pembimbingan dapat meningkatkan pengetahuan guru tentang pengembangan profesi; meningkatkan motivasi guru untuk melakukan kegiatan pengembangan profesi; meningkatkan motivasi guru untuk menulis PTK; meningkatkan aktivitas menulis bagi peserta Bimlat dan dapat meningkatkan profesionalisme guru.

Sebaiknya pihak yang berwenang memfasilitasi pelaksanaan Bimlat secara lebih intensif, agar para guru lebih kompeten dan lebih professional sehingga guru bisa menemukan sendiri permasalahan yang dihadapi di kelas dan menemukan solusi permasalahan tersebut. Sebagai hasilnya guru mampu melaksanakan pembelajaran seperti yang diamanahkan oleh standar proses, akibatnya peserta didik bisa menikmati pembelajaran dengan nyaman yang endingnya prestasi belajar peserta didik dapat meningkat. Sebaiknya pihak yang berwenang memfasilitasi pelaksanaan Bimlat secara lebih intensif, agar berdaya guna dan berhasil guna sehingga para guru lebih kompeten dan lebih professional. Hal ini akan berakibat pada peningkatan kualitas pembelajaran di kelas yang akhirnya akan mempercepat tercapainya tujuan pendidikan nasional. Guru perlu selalu berusaha meningkatkan kompetensinya melalui pengembangan profesi secara berkelanjutan. Disamping itu pemerintah juga perlu mempermudah prosedur pengusulan angka kredit agar tidak ada kendala dalam kenaikan pangkat guru.

\section{DAFTAR PUSTAKA}

Agus Purnama (2015). Peningkatan Kemampuan Melakukan PTK melalui Bimlat Guru bahasa Inggris di Bantul. Jurnal Telkomdik Vol. VIII no. 9.

Balai Dikmen KP (2020). Data Kenaikan Pangkat Guru Tahun 2020.

BKPP. (2020). Kondisi Kepegawaian di Kulon Progo. From https://satudata.kulonprogokab.go.id/index.php/lihat/dda_detil/92/kondisikepegawaian-kabupaten-kulon-progo.

Dinisiswani dan Suharno (2016). PTK dengan Pembelajaran Berbasis Kearifan Lokal dan Penulisan Artikel Ilmiah. Jurnal Ilmiah Pendidikan. Vol. IX no. 2.

H, Rahmatul., Novri, D Asmara., R, Suci Putri. (2020). Pelatihan dan Pembimbingan Penelitian Tindakan Kelas (PTK) pada Guru TK Se-Kabupaten Dharmasraya. Karya Ilmiah Pengabdian Masyarakat, 1 (3), November 2020 - 175. e- ISSN 2722-2004.

http://journal.neolectura.com/index.php/Kangmas.

Madzuki dan Muhammad Noor Kholid (2017). Pengembangan Kemampuan Penelitian dan Penulisan Karya Ilmiah bagi Guru Matematika SMA/SMK Muhammadiyah di Klaten dan Sukoharjo.

Martinis Yamin (2006). Sertifikasi Profesi Keguruan di Indonesia. Jakarta: gaung Persada Press.

Mustofa (2007). Upaya pengembangan Profesionalisme Guru di Indonesia. Jurnal Ekonomi dan Pendidikan. Vol. 4 no. 1.

I Gede Astawan, Ni Wayan Arini, \& I Gusti Ngurah Japa. (2019). Pelatihan Penulisan Karya Ilmiah Bagi Guru-Guru SD Gugus VII Kecamatan Sukasada, Kabupaten Buleleng. 
International Journal of Community Service Learning. Volume 3, Number 3, Tahun 2019, pp. 116-121, P-ISSN: 2579 -7166 E-ISSN: 2549-6417, From https://ejournal.undiksha.ac.id/index.php/IJCSL

Padrul Jana dan Bayu Pamungkas (2018). Pelatihan PTK bagi Guru SD Negeri Guwosari. Jurnal Abdimas Dewantara, Vol.1 no. 1.

Subakdi, 2018. Meningkatkan Keterampilan Menyusun PTK melalui Pembimbingan Guru Kelas VII SMP Binaan di Dinas Pendidikan dan Kebudayaan Kabupaten Sragen Semester 1 Tahun Pelajaran 2017/2018. Varia Pendidikan, Vol. 30, No. 1, Juli 2018: 84-88. ISSN: 0852-0976.

Sujarwo (2020). Strategi Pembelajaran Orang Dewasa (Pendekatan Andragogi). From http://staff.uny.ac.id/sites/default/files/penelitian/Dr.\%20Sujarwo,\%20M.Pd./Makala h-Strategi\%20Pembelajaran\%200rang\%20dewasa\%20(Repaired).pdf

Surya Dharma, 2008. Eksplorasi pemahaman peserta tentang PTK melalui pendekatan andragogy, penyampaian materi Bimlat menggunakan Pendekatan Andragogy. Depdiknas, 2008.

Sigit Pambudi, 2018. Upaya Meningkatkan Profesionalisme Guru Melalui Pelatihan Penelitian Tindakan Kelas di SMK Muhammadiyah 1 Bantul. ELINVO (Electronics, Informatics, and Vocational Education), November 2018; 3(2): 61- 64. ISSN 2580-6424 (printed), ISSN 2477-2399 (online,) DOI: 10.21831/elinvo.v3i2.23460

Somatanaya, Linda Herawati, \& Setya Wahyuningsih. (2017). Pelatihan PTK bagi Peningkatan Karier Guru SD di Kota Tasikmalaya. Jurnal Pengabdian Masyarakat, Jurnal Siliwangi. Vol. 3 no.1. ISSN: 2477-6629. 